\title{
Biological and Molecular Characterization of the Cucurbit aphid-borne yellows virus Affecting Cucurbits in Tunisia
}

\author{
M. Mnari-Hattab, Laboratoire de protection des végétaux, Institut National de la Recherche Agronomique de \\ Tunisie, 2049 Ariana, Tunisie; N. Gauthier, IRD, UMR CBGP (INRA/IRD/Cirad/Montpellier SupAgro), Campus \\ international de Baillarguet, CS 30016, F-34988 Montferrier-sur-Lez cedex, France; and A. Zouba, Centre régional \\ de Recherches en agriculture oasienne de Déguache 2260 Tozeur, Tunisie
}

\begin{abstract}
Mnari-Hattab, M., Gauthier, N., and Zouba, A. 2009. Biological and molecular characterization of the Cucurbit aphid-borne yellows virus affecting cucurbits in Tunisia. Plant Dis. 93:10651072.

Surveys of yellowing viruses under nonheated and geothermal heated plastic tunnels and in open field crops of melon (Cucumis melo), cucumber (C. sativus), zucchini (Cucurbita pepo), squash (C. maxima), watermelon (Citrullus lanatus), and ware cucurbit (Ecballium elaterium) were carried out year-round during 2000-2001, 2003, and 2004 in the major cucurbit-growing areas in Tunisia. Severe yellowing symptoms on older leaves of cucurbits were observed in open fields and under plastic-tunnel production systems. These yellowing symptoms and large populations of aphids (Aphis gossypii) on a diversity of cucurbit crops in Tunisia support the hypothesis of a viral cause of the disease. Virus identification using double-antibody sandwich enzyme-linked immunosorbent assay (DAS-ELISA), followed by reverse transcription-polymerase chain reaction (RT-PCR) and immunocapture (IC)-RT-PCR showed that Cucurbit aphid-borne yellows virus (CABYV) was largely distributed in melon, cucumber, zucchini, squash, and watermelon crops. Ware cucurbit (E. elaterium) and lettuce (Lactuca sativa) crops were identified as potential CABYV reservoirs. The RT-PCR-amplified partial coat protein (CP) and P4 genes were cloned and sequenced from nine Tunisian CABYV isolates. CP and P4 gene nucleotide and amino acid sequence comparisons as well as phylogenetic reconstructions showed that the Tunisian isolates clustered into two major subgroups. Comparisons with CABYV sequences retrieved from GenBank showed high nucleotide and $\mathrm{CP}$ amino acid identities, and close relationships of the Tunisian isolates with Italian and French isolates.
\end{abstract}

Cucurbit crops are of great economic importance in many Mediterranean countries. In Tunisia, the most important cucurbit crop is watermelon (Citrullus lanatus (Thunb.) Matsum \& Nakai) with 14,440 ha. Melon (Cucumis melo L.) is the second most economically important cucurbit and is grown year-round, with more than 8,060 ha of melon fields with a yield of more than 25 metric tons/ha. About 1,700 ha of cucumber (C. sativus L.) and 4,500 ha of zucchini (Cucurbita pepo L.) and squash (C. maxima L.) are grown (2). Due to the favorable Mediterranean climate, most cucurbits are grown year-round. Cucurbits are cultivated in Tunisia in nonheated and geothermal heated plastic tunnels, respectively, from December to April and from October to January. They are also grown in open fields from March to November depending on the region (23).

In recent decades, more than 35 different viruses affecting Cucurbitaceae have

Corresponding author: Monia Mnari-Hattab

E-mail: Hattab.monia@iresa.agrinet.tn

Accepted for publication 30 April 2009.

doi:10.1094/PDIS-93-10-1065

(C) 2009 The American Phytopathological Society been reported worldwide (42). The three most frequent and economically important viruses worldwide are Zucchini yellow mosaic virus (ZYMV), Watermelon mosaic virus (WMV), and Papaya ringspot virus (PRSV-W) (28). Yellowing diseases have been observed in protected crops and open field-grown cucurbits since 1980 $(8,12,15,24,26,29,33,48,51,52)$. In Tunisia, the first yellowing symptoms were observed under nonheated plastic tunnels in the Ariana region (M. Mnari-Hattab, unpublished data). Since then, the distribution and incidence of these symptoms have been monitored in plastic tunnels and open field crops.

Disease symptoms appear, as first described by Lecoq et al. (29), as chlorotic spots on lower leaves with interveinal areas becoming chlorotic. Leaves with symptoms are also thickened and appear brittle. These symptoms are often attributed to nutritional disorders (mainly to $\mathrm{Mg}^{2+}$ and $\mathrm{Mn}^{2+}$, or even to pesticide phytotoxicity. However, the early appearance of some plants with symptoms near plastic tunnel openings (doors and windows), the rapid spread of symptoms, the ineffective addition of nutrients, and the presence of high aphid populations (i.e., a known plant virus vector) supported the hypothesis of a phytovirus-associated disease. The yellow- ing symptoms observed differed considerably from those associated with the six viruses previously known to infect cucurbits in Tunisia, namely Cucumber mosaic virus (CMV), ZYMV, WMV, PRSV-W, Zucchini yellow Fleck virus (ZYFV), and Squash mosaic virus (SqMV) (36). Symptoms on affected plants are more similar to those caused by the aphid-transmitted virus Cucurbit aphid-borne yellows virus (CABYV) (29), or even similar to criniviruses. Cucurbits infected by Cucurbit yellow stunting disorder virus (CYSDV) $(8,51)$ and Beet pseudo-yellows virus (BPYV) induce similar yellowing symptoms (34). These two viruses are transmitted by the whitefly species $B e$ misia tabaci and Trialeurodes vaporariorum, respectively.

CABYV belongs to the genus Polerovirus of the family Luteoviridae. It is a member of the yellowing complex affecting cucurbits and is transmitted persistently by Aphis gossypii Glover and Myzus persicae Sulzer $(28,29)$. Mechanical transmission has never been reported $(11,13,14,28,29)$. Over the past two decades, CABYV has become more widespread throughout the Mediterranean basin and other regions $(4,7,25,29,31,39,48,52)$. CABYV can infect most cucurbit crops including melon, cucumber, watermelon, and zucchini (29). Moreover, CABYV was detected in natural infection within three common weeds (Capsella bursa-pastoris (L.) Medicus, Lamium amplexicaule L., and Senecio vulgaris L.) known to be reservoirs of CMV, WMV in France $(27,29,43)$, and on ware cucurbit Ecballium elaterium (L.) T. Richard (39). This virus severely reduces yields in melon and cucumber production by reducing the number of fruits per plant due to high percentages of flower abortion (40 and 51\%, respectively) but does not affect the fruit shape or quality (29).

In the present study, a large-scale survey was performed in open fields and in nonheated and geothermal heated plastic tunnels (2000-2001, 2003, and 2004) in order to identify the causal agent of the observed yellowing disease of cucurbits. To achieve this, double-antibody sandwich enzymelinked immunosorbent assay (DASELISA) and molecular methods such as reverse transcription-polymerase chain reaction (RT-PCR) and immunocapture 
(IC)-RT-PCR were applied for detection of CABYV. Aphid transmission was performed during CABYV isolation. Sequencing and phylogenetic analyses of $\mathrm{P} 4$ and coat protein $(\mathrm{CP})$ encoding genes were performed for some representative local isolates in order to investigate their molecular variability and relationships with other CABYV isolates from various geographical and plant origins.

\section{MATERIALS AND METHODS}

Field surveys. Cucurbit leaf samples from melon, cucumber, zucchini, squash, watermelon, and several weeds found in and adjacent to the cucurbits crops were collected from the major cucurbit growing areas in Tunisia. Samples with characteristic virus-like symptoms such as severe yellowing symptoms and thickening of older leaves of cucurbits in open fields and under plastic-tunnel cultivation were collected. Some asymptomatic leaves were also collected from plastic tunnels and open fields during the surveys conducted in 2000-2001, 2003, and 2004. Respectively, a total of 109,90 , and 131 cucurbit leaf samples were collected (Table 1). Weed leaf samples were collected by the end of culture from plants with or without interveinal chlorosis and yellowing symptoms during the second and third year's surveys (i.e., 2003 and 2004). They were taken from the inner and outer borders of open fields with heavily infected cucurbit crops and near the plastic tunnels in all surveyed regions. A total of 276 plants belonging to 38 species and 17 families were also tested for CABYV infections.

Depending on the time-lag before subsequent analysis or virus transmission experiments, the plant material was either maintained in a plastic bag at $4^{\circ} \mathrm{C}$ for about 1 week or stored by desiccation of small amounts of infected leaf materials over calcium chloride $\left(\mathrm{CaCl}_{2}\right)$ at $4{ }^{\circ} \mathrm{C}(6)$.

Serological CABYV detection. Serological assays were carried out using the standard DAS-ELISA according to Clark and Adams (10). A total of 330 ELISAs were performed. The CABYV antisera were purchased from BIO-RAD Phytodiagnostics (France) and used according to the manufacturer's protocol. An infected sample of CABYV-N used as a positive control was kindly provided by H. Lecoq (INRA-Monfavet Cedex, France). Samples showing optical density (OD) values higher than twice the average of the negative control were considered positive.

Virus isolation. Apterous adults of nonviruliferous $A$. gossypii originally collected from open field crops of melon in the Ariana region of Tunisia in 2003 were reared on zucchini. Some representative leaf samples collected from different regions and species that are positive in CABYV DAS-ELISA can be co-infected with other viruses already established in Tunisia such as CMV, WMV, ZYMV, PRSV-W, or ZYFV, which are transmitted in a nonpersistent manner. In order to spe- cifically isolate CABYV and confirm the presence of the virus by RT-PCR amplification, cloning, and sequencing, at least two successive transmission periods of 30 to $36 \mathrm{~h}$ were performed to avoid all nonpersistently transmitted viruses. The petioles of infected leaves were placed on moistened filter paper or directly in water and maintained in plastic boxes or bags to maintain the humidity. From 50 to 80 nonviruliferous larvae and young apterous adults of $A$. gossypii were allowed to feed for 30 to $36 \mathrm{~h}$ on infected leaves. Subsequently, each healthy seedling of melon or zucchini with 2 to 3 leaves grown under individual cages received a group of 10 to 15 aphids for 3 days. After this period, aphids were killed with insecticide (Methomyl $1.5 \mathrm{~g} /$ liter; DuPont International Operations S.A., Geneva Switzerland), and plants were transferred to an insect-proof Plexiglas house, which was maintained at 20 to $28^{\circ} \mathrm{C}$. Development of characteristic CABYV-like symptoms was monitored for 4 to 5 weeks following inoculation.

RT-PCR, cloning, and sequencing of Tunisian CABYV isolates. Total RNA was extracted from fresh leaf tissue or from desiccated tissues according to the technique of Celix et al. (8). About $300 \mathrm{ng}$ of total RNA were used as a template for RT-PCR.

In order to amplify a 554-nucleotide region of the coat protein and other hypothetical protein genes, one set of primers

Table 1. Cucurbit leaves collected under geothermal heated and nonheated plastic tunnels, and in open field-grown cucurbit crops during the 2000-2001, 2003, and 2004 surveys, and Cucurbit aphid-borne yellows virus (CABYV) occurrence in the samples

\begin{tabular}{|c|c|c|c|c|c|}
\hline \multirow[b]{2}{*}{ Type of cultures } & \multirow{2}{*}{$\begin{array}{l}\text { Region } \\
\text { (sampled units) }\end{array}$} & \multirow[b]{2}{*}{ Plant species } & \multirow{2}{*}{$\begin{array}{l}\text { Symptomatic plants/ } \\
\text { total plants collected }\end{array}$} & \multicolumn{2}{|c|}{$\begin{array}{l}\text { CABYV detection test used } \\
\text { (no. positive results) }\end{array}$} \\
\hline & & & & DAS-ELISA ${ }^{\mathrm{a}}$ & RT-PCR or IC-RT-PCR \\
\hline \multicolumn{6}{|l|}{ 2000-2001 survey } \\
\hline Nonheated plastic tunnel & Sahel (5) & Melon & $27 / 29$ & 14 & - \\
\hline GeoTunnel & South (8) & Melon & $38 / 41$ & 12 & - \\
\hline Open field & North (3) & Melon & $7 / 9$ & 5 & - \\
\hline Open field & Sahel (3) & Watermelon & $11 / 13$ & 3 & - \\
\hline Open field & Sahel (4) & Zucchini & $6 / 9$ & 6 & - \\
\hline \multirow[t]{2}{*}{ Open field } & Sahel (4) & Squash & $5 / 8$ & 3 & - \\
\hline & $(27)$ & & $94 / 109$ & 43 & - \\
\hline \multicolumn{6}{|l|}{2003 survey } \\
\hline GeoTunnel & South (7) & Melon & $27 / 27$ & 13 & 17 \\
\hline GeoTunnel & South (4) & Cucumber & $12 / 18$ & 5 & 8 \\
\hline GeoTunnel & South (1) & Watermelon & $5 / 6$ & 0 & 2 \\
\hline Open field & Sahel (1) & Melon & $11 / 13$ & 7 & 9 \\
\hline Open field & Sahel (2) & Zucchini & $12 / 14$ & 7 & 9 \\
\hline \multirow[t]{2}{*}{ Open field } & North (1) & Melon & $11 / 12$ & 6 & 9 \\
\hline & $(16)$ & & $78 / 90$ & 38 & 54 \\
\hline \multicolumn{6}{|l|}{2004 survey } \\
\hline GeoTunnel & South (12) & Melon & $35 / 42$ & 14 & 19 \\
\hline GeoTunnel & South (1) & Cucumber & $2 / 3$ & 2 & 2 \\
\hline GeoTunnel & South (1) & Watermelon & $4 / 5$ & 2 & 3 \\
\hline Open field & Center (2) & Melon & $7 / 9$ & 4 & 5 \\
\hline Open field & Center (1) & Watermelon & $4 / 6$ & 4 & 4 \\
\hline Open field & Sahel (2) & Zucchini & $9 / 10$ & 6 & 8 \\
\hline Open field & Sahel (5) & Melon & $23 / 25$ & 13 & 19 \\
\hline Open field & Sahel (4) & Watermelon & $8 / 8$ & 2 & 2 \\
\hline \multirow[t]{2}{*}{ Open field } & North (6) & Melon & $21 / 23$ & 10 & 15 \\
\hline & (34) & & $113 / 131$ & 57 & 77 \\
\hline
\end{tabular}

\footnotetext{
${ }^{\text {a }}$ Double-antibody sandwich enzyme-linked immunosorbent assay.

${ }^{b}$ Reverse transcription-polymerase chain reaction or immunocapture RT-PCR.
} 
was used. The forward (CB11) and reverse (CB12) primers were designed based on highly conserved regions of the $\mathrm{CP}$ gene sequences of the reference isolate CABYV-N (20) (X76931) and some related isolates (X13063, X83110) available in GenBank databases (39).

Detection of CABYV was based on two methods, namely one-tube RT-PCR and IC-RT-PCR assays using the Access RTPCR system from Promega according to the manufacturer's protocol. Reactions were performed in $50 \mu \mathrm{l}$ using $0.3 \mu \mathrm{g}$ of total RNA per tube. Immunocapture (IC) was performed according to Wetzel and collaborators (50). Each PCR tube $(0.2 \mathrm{ml}$ Biozym) was incubated for $3 \mathrm{~h}$ at $37^{\circ} \mathrm{C}$ with $100 \mu \mathrm{l}$ of CABYV antiserum diluted in carbonate buffer, $\mathrm{pH}$ 9.6, as used in ELISA, then washed three times with 150 $\mu \mathrm{l}$ of PBST at $\mathrm{pH}$ 7.4.

The IC-RT-PCR or RT-PCR reactions consist of one cycle of $48^{\circ} \mathrm{C}$ for $45 \mathrm{~min}$ and a second cycle of $94^{\circ} \mathrm{C}$ for 2 min followed by 35 cycles (denaturing at $94^{\circ} \mathrm{C}$ for $30 \mathrm{~s}$, annealing at $58^{\circ} \mathrm{C}$ for $1 \mathrm{~min}$, and extension at $68^{\circ} \mathrm{C}$ for $1 \mathrm{~min}$ ) and terminated with a final extension cycle at $68^{\circ} \mathrm{C}$ for $10 \mathrm{~min}$.

PCR amplicons of $554 \mathrm{bp}$ were obtained from the following nine selected Tunisian CABYV isolates: $9 \mathrm{FB}$ and $\mathrm{G}$ isolates, respectively, collected on melon from Sousse and Ariana, 14S and 59S on cucumber from Kebili and Tozeur, ESH-25 on zucchini from Sousse, AZ on watermelon from Kairouan, and EC1 and EC3 on E. elaterium and LR on lettuce from Ariana). These amplicons were purified (Wizard PCR DNA purification system, Promega, Madison, WI, USA) and ligated into the pGem-T Easy vector (Promega) having a size of $3,015 \mathrm{bp}$ according to the manufacturer's recommendations. Competent cells of Escherichia coli (strain JM 109, Promega) were transformed with the resultant recombinant plasmids. The re- combinant plasmid DNA was purified using the Qiaprep Spin Miniprep kit (Qiagen GmbH, Hilden, Germany) before sequencing. Thus, for each insert, two independent clones were sequenced in both directions with $\mathrm{T} 7$ and Sp6 primers using an automated ABI3730 DNA sequencer (Applied Biosystems, Foster City, CA, USA).

Sequence analysis and phylogenetic relationships. The nucleotide sequences obtained and the corresponding CP and P4 amino acid sequences were aligned with ClustalW (47) and compared among them. Only those uncovering different haplotypes were included in the analyses. Pairwise nucleotide and amino acid divergences were based on the percentage of shared nucleotide and amino acid identity.

Additional CABYV nucleotide and thus $\mathrm{CP}$ and $\mathrm{P} 4$ amino acid sequences were obtained from the EMBL sequence database and used for comparison with the sequences obtained in this study. Standard indices of genetic variations were calculated using PAUP* software (46). Phylogenetic trees were reconstructed by a distance method using the neighborjoining (NJ) algorithm (44), the Maximum-Likelihood (ML) (16) and Maximum-Parsimony (MJ) (18) criteria as implemented in PAUP* (46). For ML, MODELTEST (41) was used to determine the most suitable model of DNA substitution. For NJ analysis, Kimura-2 parameter distances were used to correct for multiple substitutions. Heuristic search conditions for ML and MP used starting trees obtained by stepwise addition with 10 random sequence addition replicates and treebisection-reconnection (TBR) random branch-swapping. Branch supports were assessed by 1,000 bootstrap resamplings as implemented in PAUP. Phylogenetic trees were rooted with nine homologous sequences from $\mathrm{CABYV}$ that originated from Italy (EF029112-13-14-15), France
(X76931), Spain (AY52653-54), and China (EF063706-07), and with six related Luteoviridae sequences encoding the CP (Beet western yellows virus AF473561, Groundnut rosette assistor virus AF195824-25-26, and Barley yellow dwarf virus AF216863-EF153722).

\section{RESULTS}

Yellowing virus detection methods. Plants suspected to be infected based on various visual characteristic symptoms (i.e., yellow mosaics, yellowing of lower leaves, necrotic or yellowing spots) were checked using two detection methods. All the visually asymptomatic samples were shown to be negative with the two detection methods (Table 2). The RT-PCR and IC-RT-PCR results yielded an expected product of $554 \mathrm{bp}$ that was amplified from the reference isolate (CABYV-N) (Fig. 1). CYSDV and BPYV can induce similar yellowing symptoms in cucurbits, but here no amplicon was produced from extracts of asymptomatic plants, RNA positive controls preparations of Cucurbit yellow stunting disorder virus (CYSDV), or Beet pseudo-yellows virus (BPYV).

The visually symptomatic samples did not universally produce positive results with DAS-ELISA and IC-RT-PCR. This was observed for all regions and years of sampling with a visual overestimation of possible CABYV infection of about $50 \%$ with regard to DAS-ELISA and $30 \%$ with IC-RTPCR. DAS-ELISA proved to be significantly less sensitive than the IC-RT-PCR. Overall, $17.7 \%$ (in 2003) and 20\% (in 2004), or about 1 out of 5 confirmed IC-RTPCR positive samples did not react with the specific antisera against CABYV used in DAS-ELISA (Table 2). When positive, the IC-RT-PCR results yielded the expected product of $554 \mathrm{bp}$ that was amplified from the reference isolate (CABYV-N).

Incidence of CABYV in Tunisian cucurbit crops and weeds. Yellowing symp-

Table 2. Results of Cucurbit aphid-borne yellows virus (CABYV) detection tests used (DAS ELISA, RT-PCR, or IC-RT-PCR) ${ }^{\mathrm{a}}$ given as percentage of infection detected, on symptomatic and asymptomatic cucurbit samples collected under geothermal heated and nonheated plastic tunnels, and in open field-grown cucurbit crops during the 2000-2001, 2003, and 2004 surveys carried out in the north, Sahel, center, and south regions of Tunisia

\begin{tabular}{|c|c|c|c|c|c|c|c|}
\hline \multirow[b]{2}{*}{$\begin{array}{l}\text { Region } \\
\text { of sampling }\end{array}$} & \multirow[b]{2}{*}{ Type of plants ${ }^{b}$} & \multicolumn{2}{|c|}{ 2000-2001 } & \multicolumn{2}{|r|}{2003} & \multicolumn{2}{|c|}{2004} \\
\hline & & $\begin{array}{l}\text { DAS ELISA } \\
(\%)^{\mathrm{c}}\end{array}$ & $\begin{array}{c}\text { RT-PCR or } \\
\text { IC-RT-PCR }(\%)^{\mathbf{c}}\end{array}$ & $\begin{array}{l}\text { DAS ELISA } \\
(\%)^{\mathrm{c}}\end{array}$ & $\begin{array}{c}\text { RT-PCR or } \\
\text { IC-RT-PCR }(\%)^{\mathbf{c}}\end{array}$ & $\begin{array}{l}\text { DAS ELISA } \\
\left(_{(\%)^{\mathrm{c}}}\right.\end{array}$ & $\begin{array}{c}\text { RT-PCR or } \\
\text { IC-RT-PCR }(\%)^{\mathrm{c}}\end{array}$ \\
\hline \multirow[t]{2}{*}{ North } & Sympt. & 71.42 & - & 54.54 & 81.81 & 47.61 & 71.42 \\
\hline & Asympt. & 0 & - & 0 & 0 & 0 & 0 \\
\hline \multirow[t]{2}{*}{ Sahel } & Sympt. & 53.06 & - & 60.83 & 78.26 & 52.50 & 72.50 \\
\hline & Asympt. & 0 & - & 0 & 0 & 0 & 0 \\
\hline \multirow[t]{2}{*}{ Center } & Sympt. & $\mathrm{NT}^{\mathrm{d}}$ & - & NT & NT & 72.72 & 81.81 \\
\hline & Asympt. & NT & - & NT & NT & 0 & 0 \\
\hline \multirow[t]{2}{*}{ South } & Sympt. & 31.57 & - & 40.90 & 61.36 & 39.02 & 58.53 \\
\hline & Asympt. & 0 & - & 0 & 0 & 0 & 0 \\
\hline \multirow[t]{2}{*}{ Total } & Sympt. & 45.74 & - & 48.71 & 69.23 & 50.44 & 68.14 \\
\hline & Asympt. & 0 & - & 0 & 0 & 0 & 0 \\
\hline
\end{tabular}

${ }^{\mathrm{a}}$ DAS ELISA = double-antibody sandwich enzyme-linked immunosorbent assay; RT-PCR = reverse transcription-polymerase chain reaction; IC-RT-PCR = immunocapture RT-PCR.

${ }^{\mathrm{b}}$ Sympt. $=$ symptomatic plants; Asympt. $=$ asymptomatic plants.

c $\%$ infection detected $=[$ (no. positive samples $) /($ no. tested samples $)] \times 100$.

${ }^{\mathrm{d}} \mathrm{NT}=$ not tested. 
toms on lower leaves were observed in all 77 sampled units. A total of 330 symptomatic and asymptomatic cucurbit leaves (Table 1) and 276 weed samples which could be potential CABYV reservoirs (data not shown) were collected from various regions in Tunisia during the survey period (2000-2001, 2003, and 2004).

Survey results showed that CABYV is widely distributed and established in the major cucurbit growing areas of Tunisia, including the northern, Sahel, southern, and central regions (Tables 1 and 2). The percentage of total infection obtained even by the less sensitive method ranged from 46 to $51 \%$ of the symptomatic samples (Table 2). All the cucurbit species (melon, cucumber, watermelon, zucchini, and squash), in all modes of production (geothermal and nonheated tunnels, open fields), and surveyed regions were affected (Tables 1 and 2). Results from all survey periods also demonstrated that, although yellowing symptoms are more frequent in southern regions than in other surveyed regions, CABYV was slightly less prevalent among southern symptomatic samples. The IC-RT-PCR method confirmed the wide distribution in space and time of CABYV by giving higher percent values of infection for each cucurbit species and regions (Table 2).

Among the 276 weeds belonging to 38 different species analyzed by IC-RTPCR, only seven samples belonging to two different species and plant families gave positive results. Four samples were ware cucurbits (E. elaterium) as previously reported (39), and three were lettuce samples collected in only one open field.
Virus transmission, genetic diversity, and relationships among CABYV isolates. Experiments showed that yellowing symptoms observed on cucurbits (melon, cucumber, zucchini, squash, watermelon, and E. elaterium) and on lettuce collected from different growing regions in 2003 and 2004 could be reproduced in young plants of melon and zucchini after transmission in persistent manner using A. gossypii. Nine isolates of CABYV were specifically isolated and confirmed infected by CABYV by RT-PCR amplification (Fig. 2, Table 3). The 554-bp sequences of the nine Tunisian CABYV isolates obtained were submitted to GenBank (Accession numbers EF187338-EF187346). When compared, the nine sequences represented seven haplotypes (Table 3 ) differing by 15 nucleotide substitutions, the most common being transitions $(73.3 \%)$. A total of $93.3 \%$ of the mutations were single nucleotide substitutions. No strong phylogenetic information could be provided by these seven haplotypes, but they often led to an amino acid change in the P4 and CP (Table 3). Only one nucleotide substitution (site 132) and one amino acid for each protein encoded (aa 44) were parsimony-informative delineating two major Tunisian groups: one group including 9FB and 14-S isolates, and another including ESH-25, AZ, 59-S, G, LR, EC1, and to a lesser extent EC3 isolates. Sequence comparisons showed that the Tunisian isolates shared 98.1 to $100 \%$ nucleotide identities, leading to 95.6 to $100 \%$ aa identities for $\mathrm{P} 4$, and 97.2 to $100 \%$ for the CP. EC3 presented the least identities with the others because of several nucleotide and amino acid differences within the sequence of this isolate.

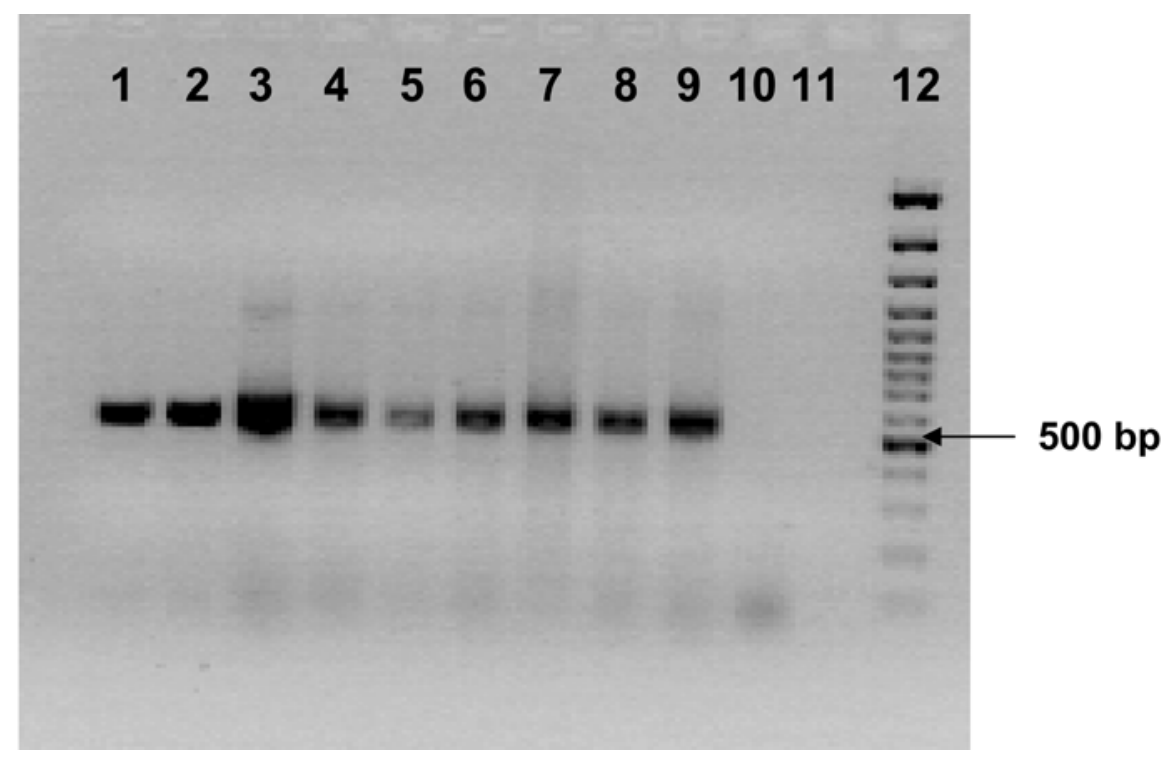

Fig. 1. Agarose gel electrophoresis (1.4\%) of immunocapture reverse transcription-polymerase chain reaction (IC-RT-PCR) products obtained after amplification with the primer pair CB11 and CB12. Lane 1: product from a reference sample Cucurbit aphid-borne yellows virus (CABYV) positive; lanes 2 to 9: various collected samples; lane 10: healthy plant; lane 11: ultrapure water (control); lane 12: molecular weight marker (Gene Ruler 100-bp ladder plus from Fermentas International Inc., Burlington, Canada).
Comparison between Tunisian isolates and nine isolates from France, Italy, Spain, and China showed that they shared 94.3 to $99.8 \%$ nt identities, 88.4 to $99.4 \%$ aa identities for $\mathrm{P} 4$, and 93.9 to $100 \%$ for the $\mathrm{CP}$ (Table 4). Tunisian isolates' nucleotide and amino acid sequences were found to be related more closely to the Italian and French isolates than to those from Spain and China. Nucleotide and amino acid sequence similarities appeared to be more closely associated with geographical origins of the isolates than with host plant. This was supported by the phylogenetic reconstructions regardless of the method used. NJ, MP, and ML analyses for which MODELTEST (41) determined that the GTR+I+G model was the statistically appropriate model for the 22 sequence data sets $($ gamma $=1.1570$, pinv $=0.205235)$ revealed comparable topologies with higher support values at the main nodes for NJ analyses (Fig. 2). The NJ reconstruction supported the division of Tunisian CABYV isolates into two major groups with the EC3 isolate being distinct from either group. Tunisian CABYV isolates were closely related to the Italian and French ones delineating a well-supported group (bootstrap value of 77), whereas the Spanish CABYV isolates were clearly shown to be more closely related to the Chinese isolates than to the other Mediterranean ones.

\section{DISCUSSION}

Yellowing virus diseases have always been responsible for significant qualitative and quantitative damage and thus economic losses in cucurbit crops and international trade. In Tunisia, cucurbits are a cash crop. In this paper, we report results of an extensive survey of cucurbit virus in Tunisia, aiming at determining the incidence and the genetic diversity of CABYV, one of the main yellowing viruses infecting not only the major cucurbit crops but also some weeds as potential reservoirs. To this end, serological and molecular diagnostic tests were used on a large number of symptomatic and asymptomatic samples.

Incidence of CABYV in Tunisian cucurbit crops and weeds. CABYV was detected by DAS-ELISA, RT-PCR, and IC-RT-PCR. In accordance with previous studies, ELISAs were not sensitive enough to detect the presence of CABYV and other Luteoviridae in plants $(17,40,49)$. Molecular tests were demonstrated to improve the detection level of CABYV and thus the reliability of the results $(8,9,22,32,40)$. In particular, the IC-RTPCR method, which does not require the extraction of viral or plant total RNA, limits the problems of contamination by RNase, is easily carried out, and provides reliable results in epidemiology of viral diseases $(35,38,45,50)$. CABYV was thus detected in naturally infected cucurbits such as melon, watermelon, zucchini, 
squash, and cucumber but also in ware cucurbits as previously reported (39).

CABYV was found in all the major cucurbit growing areas and cucurbit crop types sampled, suggesting that the virus has been spreading since its first observation (1990, M. Mnari-Hattab, unpublished data) and is now well established in Tunisia. As previously demonstrated by other authors $(28,30)$, CABYV can be found in a great diversity of areas and environments and is often more widespread than believed. Indeed, for many years, CABYVassociated yellowing symptoms on plants have been wrongly attributed to nutritional
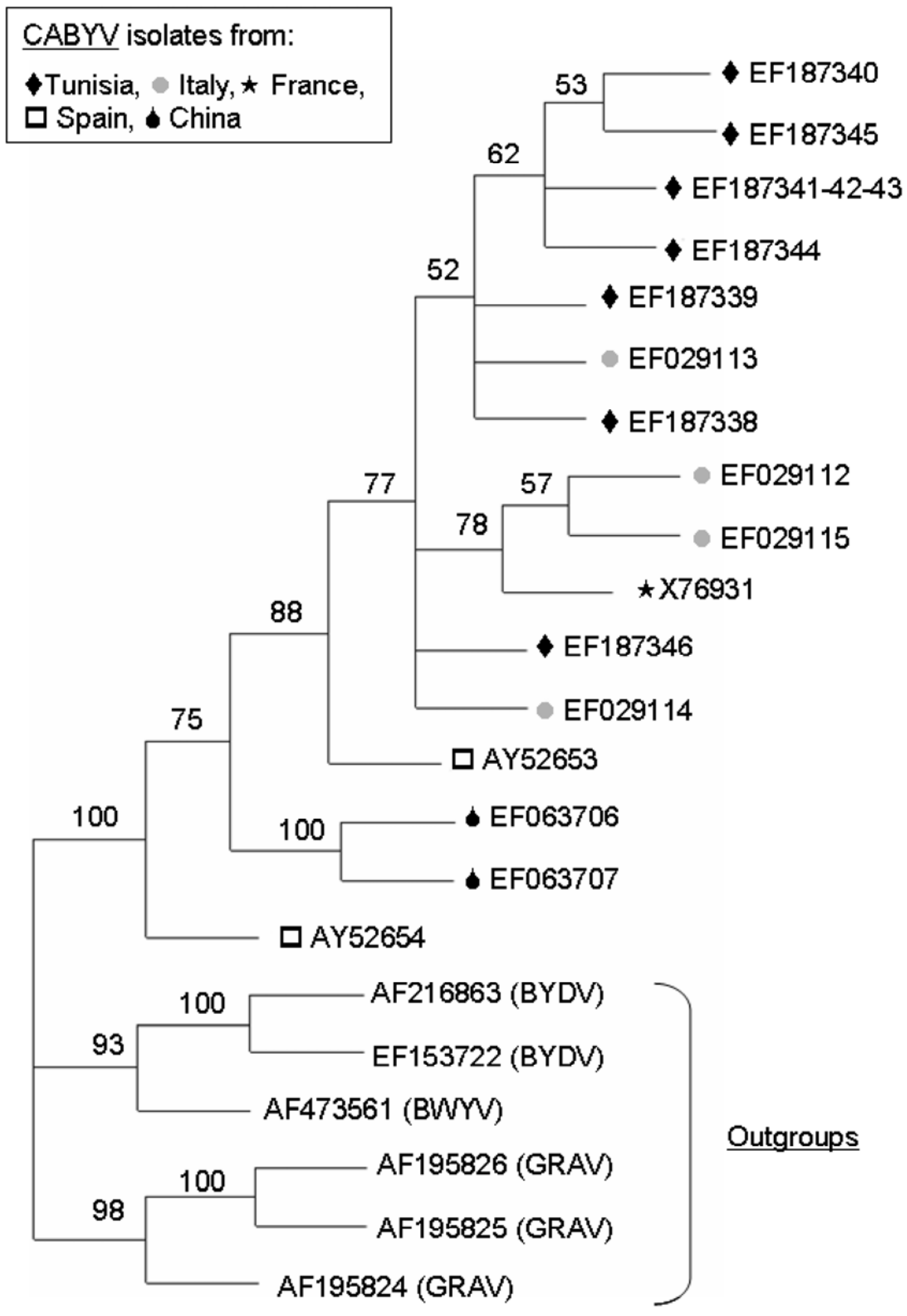

Fig. 2. Genetic relationships among the nine Tunisian Cucurbit aphid-borne yellows virus (CABYV) isolates analyzed in our study, nine other CABYV isolates of which sequences were retrieved from GenBank, and six related luteoviruses based on the nucleotide sequence encoding the partial coat protein and P4 genes. Phylogenetic relations were depicted in a neighbor-joining tree based on Kimura-2 distances after 1,000 bootstrap resamplings of the sequence data. The following luteoviruses were used as outgroups (BYDV = Barley yellow dwarf virus, BWYV: Beet western yellows virus, GRAV: Groundnut rosette assistor virus). Bootstrap values over 50 are shown at the corresponding nodes. Scores of the most parsimonious tree $(\mathrm{Length}=499 ; \mathrm{CI}=0.8227 ; \mathrm{RI}=$ 0.867). 
disorders in Tunisia (1990, M. MnariHattab, unpublished data), other abiotic stresses, or phytovirus agents, leading to underestimation of the real incidence of CABYV $(1,4,25,26,28,31,39,48,52)$. Likewise, some plants that are visually symptomatic due to nutrient deficiency or natural senescence could be misinterpreted as virus infected, as possibly observed in the south of Tunisia where CABYV was less prevalent than in other Tunisian regions in spite of more yellowing symptomatic plants. Also, the possibility that other virus variant species belonging to Polerovirus or Crinivirus genera could be responsible for such yellowing symptoms could not be excluded. Further investigations will be done to biologically confirm the absence of any virus variant missed when using serological and molecular tests.

This study clearly demonstrated that in Tunisia, CABYV is one of the most common yellowing diseases affecting cucurbits in open-field crops, and under heated and nonheated tunnels. Even the less sensitive method of detection (DAS-ELISA) showed

Table 3. Nucleotide, P4, and coat protein (CP) amino acid polymorphic sites from the 554-bp sequence alignments obtained from the nine Tunisian Cucurbit aphid-borne yellows virus (CABYV) isolates ${ }^{\mathrm{a}, \mathrm{b}, \mathrm{c}}$

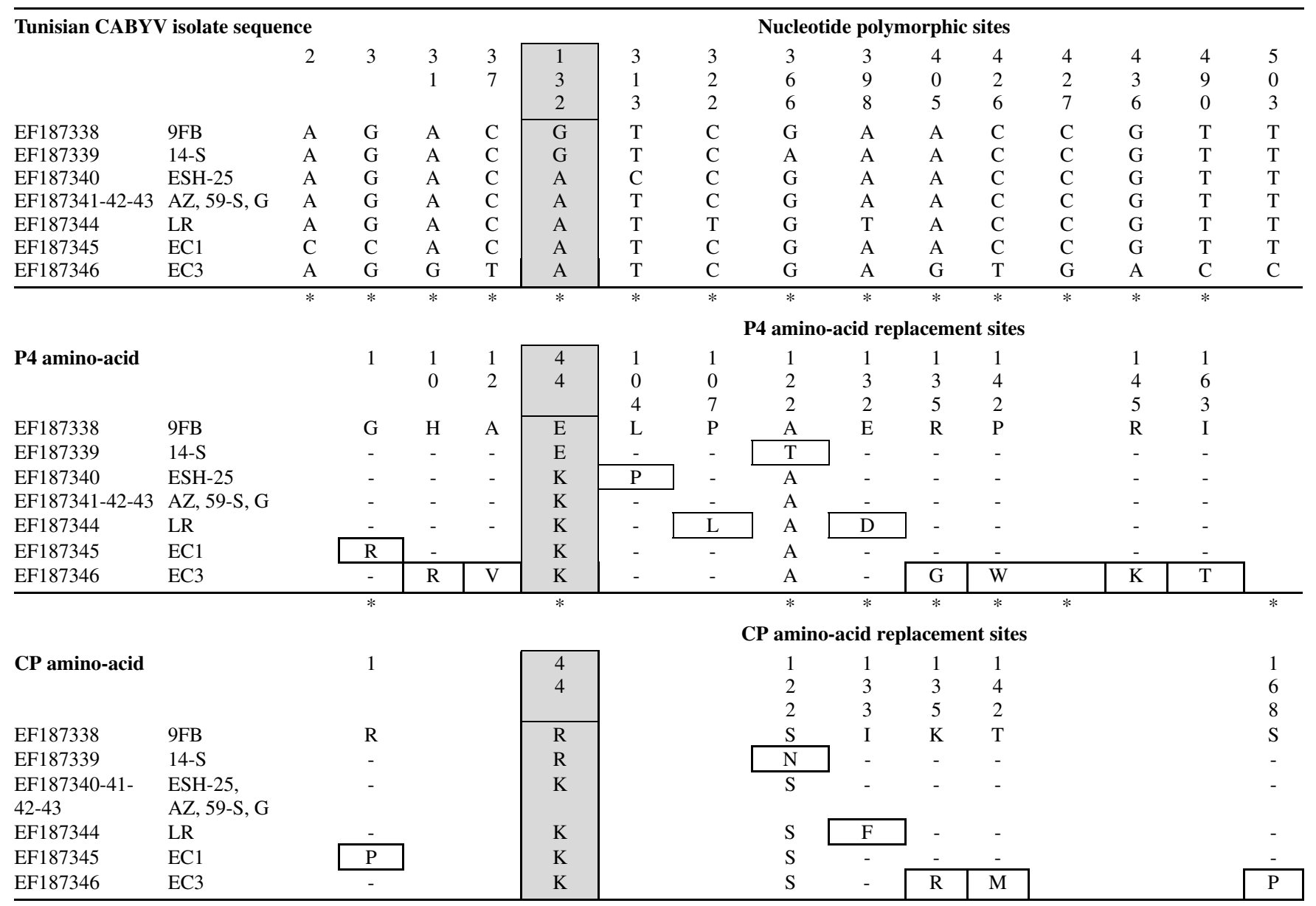

a In gray cell, the nucleotide and amino-acid parsimony-informative site.

${ }^{\mathrm{b}}$ In surrounded cell, a unique single amino acid change.

c *, Asterisks under alignment represent sites with amino acid (aa) replacement. -, Same aa as in the reference aa sequence (EF187338).

Table 4. Sequence identities (in percentage) between Tunisian isolates and nine other Cucurbit aphid-borne yellows virus (CABYV) sequences retrieved from GenBank databases

\begin{tabular}{|c|c|c|c|c|c|c|c|c|}
\hline Source & Isolate & 9FB & $14-S$ & ESH-25 & AZ, 59-S, G & $\mathbf{L R}$ & EC1 & EC3 \\
\hline Tunisia & $\begin{array}{l}\text { 9FB } \\
\text { 14-S } \\
\text { ESH-25 } \\
\text { AZ, 59-S, G } \\
\text { LR } \\
\text { EC1 } \\
\text { EC3 }\end{array}$ & - & $\begin{array}{c}99.8 \\
-\end{array}$ & $\begin{array}{c}99.6 \\
99.4 \\
-\end{array}$ & $\begin{array}{c}99.8 \\
99.6 \\
99.8 \\
-\end{array}$ & $\begin{array}{c}99.4 \\
99.2 \\
99.4 \\
99.6 \\
-\end{array}$ & $\begin{array}{c}99.4 \\
99.2 \\
99.4 \\
99.6 \\
99.2 \\
-\end{array}$ & $\begin{array}{c}98.3 \\
98.1 \\
98.3 \\
98.5 \\
98.1 \\
98.1 \\
-\end{array}$ \\
\hline Italy & $\begin{array}{l}\text { EF029112.1 } \\
\text { EF029113.1 } \\
\text { EF029114.1 } \\
\text { EF029115.1 }\end{array}$ & $\begin{array}{l}98.0 \\
99.8 \\
99.6 \\
98.7\end{array}$ & $\begin{array}{l}97.8 \\
99.6 \\
99.4 \\
98.5\end{array}$ & $\begin{array}{l}97.6 \\
99.4 \\
99.2 \\
98.3\end{array}$ & $\begin{array}{l}98.5 \\
99.6 \\
99.4 \\
95.4\end{array}$ & $\begin{array}{l}97.4 \\
99.2 \\
99.0 \\
95.2\end{array}$ & $\begin{array}{l}97.4 \\
99.2 \\
99.0 \\
98.1\end{array}$ & $\begin{array}{l}97.0 \\
98.1 \\
98.0 \\
97.4\end{array}$ \\
\hline France & X76931.1 & 99.0 & 98.9 & 98.7 & 98.9 & 98.5 & 98.5 & 97.8 \\
\hline Spain & $\begin{array}{l}\text { AY529653.1 } \\
\text { AY529654.1 }\end{array}$ & $\begin{array}{l}98.3 \\
95.4\end{array}$ & $\begin{array}{l}98.1 \\
95.4\end{array}$ & $\begin{array}{l}98.0 \\
95.2\end{array}$ & $\begin{array}{l}98.1 \\
95.4\end{array}$ & $\begin{array}{l}97.8 \\
95.2\end{array}$ & $\begin{array}{l}97.8 \\
95.0\end{array}$ & $\begin{array}{l}97.0 \\
95.2\end{array}$ \\
\hline China & $\begin{array}{l}\text { EF063706.1 } \\
\text { EF063707.1 }\end{array}$ & $\begin{array}{l}95.6 \\
95.4\end{array}$ & $\begin{array}{l}95.4 \\
95.2\end{array}$ & $\begin{array}{l}95.0 \\
95.2\end{array}$ & $\begin{array}{l}95.4 \\
95.2\end{array}$ & $\begin{array}{l}95.0 \\
94.9\end{array}$ & $\begin{array}{l}95.0 \\
94.9\end{array}$ & $\begin{array}{l}94.5 \\
94.3\end{array}$ \\
\hline
\end{tabular}


that 46 to $51 \%$ of the symptomatic plants collected were infected by CABYV. ICRT-PCR tests reached percentages of nearly $70 \%$. These extensive surveys also revealed that weeds could be infected by CABYV. Among a total of 276 weed samples belonging to 38 species and 17 families checked by IC-RT-PCR, the symptomatic cucurbit weed E. elaterium and for the first time in open field lettuce ( $L . s a$ tiva, Asteraceae) were shown to be CABYV positive. However, CABYVinfected lettuces were very locally detected (i.e., one field) and involved a small sample size (three positive samples out of three tested). Further targeted surveys must therefore be done to learn more about the incidence of CABYV on lettuce, which could play a critical role in the ecology and epidemiology of the virus as a potential reservoir host. Lecoq et al. (29) demonstrated that CABYV can naturally infect some weeds such as Lamium amplexicaule, Senecio vulgaris, Capsella bursapastoris, and Bryonia dioica. They discussed the differential host range of CABYV and concluded that the virus can also be hosted by Beta vulgaris, L. sativa, Crambe abyssinica, Papaver rhoeas, and Montia perfoliata.

The number of weed species that proved to be CABYV positive in Tunisia seems to be lower than in some Mediterranean countries. This may be explained by the relative incidence of the two aphid-vectors, A. gossypii and M. persicae, in and around the cucurbit crops. In Tunisia, cucurbits were cultivated year-round. A. gossypii is considered the primary insect pest on cucurbits in Tunisia, and is also known as the melon aphid; whereas $M$. persicae is mainly considered a pest of pepper and potato $(5,37)$. The same situation has been described in Spain where A. gossypii is the major cucurbit pest (19). In other Mediterranean countries such as France and Portugal, both $M$. persicae and $A$. gossypii are cucurbit pests and are involved in the transmission of CABYV $(28,29)$, increasing the possible incidence of CABYV on weeds around cucurbit production.

Genetic diversity and relationships among CABYV isolates. From this study, nine Tunisian CABYV isolates collected from different crops and regions were sequenced (EF187338-EF187346) and added to the limited number of CABYV sequences already present in the GenBank database. Comparison among these nine Tunisian isolates and data retrieved from GenBank examined variation in partial nucleotide and amino acid sequences of the $\mathrm{P} 4$ and the $\mathrm{CP}$ genes.

Eight of these nine Tunisian CABYV isolates displayed a very low level of genetic diversity (99.2 to $100 \%$ of nucleotide identity); the EC3 isolate collected from a sample of the cucurbit weed E. elaterium shared comparatively fewer nucleotide and amino acid identities $(\approx 98 \%$ nt identity, $\approx 95.6 \%$ aa identity for $\mathrm{P} 4$, and $\approx 97.2 \%$ for $\mathrm{CP})$ with the others. The comparison between the resulting nucleotide and amino acid haplotypes revealed few substitutions, including only one shared character which leads to delineation of two possible subgroups present in Tunisia. The delineation of the two subgroups does not seem to be host-plant or geographically associated. Further CABYV Tunisian sequences should be determined to clarify differences between the two CABYV isolate groups in Tunisia.

The comparison among the $18 \mathrm{CABYV}$ isolate sequences provided new insights into the level of divergence among CABYV isolates in Tunisia. Percentages of aa differences between the various isolates compared were as high as $11.6 \%$ for $\mathrm{P} 4$ and $6 \%$ for $\mathrm{CP}$ (against the most divergent Spanish and Chinese CABYV isolates). Low level of genetic variability is not the rule within in the Luteoviridae family (21). A similar range of genetic variation has also been found for other poleroviruses (i.e., the Beet polerovirus complex and Cereal yellow dwarf polerovirus) and to a lesser extent in the Potato leaf roll virus (21).

When compared with nine isolates from France, Italy, Spain, and China, genetic diversity analyses and phylogenetic trees generated from CP gene nucleotide and aa sequences clearly showed that Tunisian CABYV isolates were more closely related to Italian and French isolates, with which they consist of a well-supported cluster, than to Spanish and Chinese isolates. Directed gene flow could contribute to that geographically based clustering. First, Tunisia primarily exchanges agricultural materials (vegetables, plants, and ornamentals) with France and Italy. Agricultural trade with Spain and China occurs at a much lower level (3). CABYV was demonstrated to be ecologically adapted to temperate environments and to infect at least 18 species belonging to seven families of host plants $(29,39,52$; L. Tomassoli and M. Meneghini, unpublished data) among which are many marketed plants. Other species unknown as potential CABYV reservoirs may also be put on the market without control. Even though some phytosanitary controls are applied, symptoms of yellowing, if observed, can be attributed to many factors such as nutrient deficiencies as seen on cucurbits, without CABYV being suspected or detected. Consequently, asymptomatic infected plants and/or viruliferous aphids on plants can be transported internationally. Because CABYV is a persistently transmitted virus, viruliferous aphids could also be transported by winds over a very long distance, that is about 1,000 km (i.e., from Minnesota to Ohio) as previously demonstrated by Zeyen et al. (53).

\section{ACKNOWLEDGMENTS}

We thank B. Falk for kindly providing positive RNA and DNA of CYSDV and BPYV, H. Lecoq for the gift of polyclonal antibodies against CABYV, and B. Nasraoui and H. Ben Salah for their critical review of this manuscript.

\section{LITERATURE CITED}

1. Abou-Jawdah, Y., Sobh, H., Fayyad, A., and Lecoq, H. 1997. First report of Cucurbit aphidborne yellows Luteovirus in Lebanon. Plant Dis. 81:1331.

2. Anonymous. 2006. Enquête sur les structures des exploitations agricoles 2004-2005. Observatoire national de l'agriculture, Ministère de l'agriculture http://www.onagri.nat.tn

3. Anonymous. 2007. Institut national de la statistique (Tunisie). http://www.ins.nat.tn/ indexfr.php

4. Bananej, K., Desbiez, C., Wipf-Scheibel, C., Vahdat, I., Kheyr-Pour, A., Ahoonmanesh, A., and Lecoq, H. 2006. First report of Cucurbit aphid-borne yellows virus in Iran causing yellows on four cucurbit crops. Plant Dis. 90:526.

5. Ben Halima-Kamel, M., and Ben Hamouda M. 1993. Les pucerons des cultures protégées et leurs ennemis en Tunisie. Tropicultura 11(2):50-53.

6. Bos, L. 1969. Experience with a collection of plant viruses in leaf materiel dried and stored over calcium chloride and a discussion of literature on virus preservation. Meded. Fac. Landbouw. Wet. Rijksuniv. Gent. 34:875-887.

7. Boubourakas, I. N., Avgelis, A. D., Kyriakopoulou, P. E., and Katis, N. I. 2006. Occurrence of yellowing viruses (Beet pseudoyellows virus, Cucurbit yellow stunting disorder virus and Cucurbit aphid-borne yellows virus) affecting cucurbits in Greece. Plant Pathol. 55:276-283.

8. Celix, A., Lopez-Sese, A., Almarza, N., Gomez-Guillamon, M. L., and Rodriguez-Cerezo E. 1996. Characterization of Cucurbit yellow stunting disorder virus, a Bemisia tabacitransmitted Closterovirus. Phytopathology 86:1370-1376.

9. Choi, S. K., Choi, J. K., Park, W. M., and Ryu, H. K. 1999. RT-PCR detection and identification of three species of cucumoviruses with a genus specific single pair of primers. J. Virol. Methods 83:67-73.

10. Clark, M. F., and Adams, A. N. 1977. Characteristics of the microplate method of the enzyme-linked immunosorbent assay for the detection of plant viruses. J. Gen. Virol. 34:475483.

11. D'Arcy, C. J., and Domier, L. L. 2005. Luteoviridae. Pages 891-900 in: Virus Taxonomy, VIIIth Report of the ICTV. C. M. Fauquet, M. A. Mayo, J. Maniloff, U. Desselberger, and L. A. Ball, eds. Elsevier/Academic Press, London.

12. Desbiez, C., Lecoq, H., Girard, M., Cotillon, A. C., and Schoen, L. 2003. First report of $\mathrm{Cu}$ curbit yellow stunting disorder virus in commercial cucumber greenhouses in France. Plant Dis. 87:600.

13. Dogimont, C., Bussemakers, A., Martin, J., Slama, S., Lecoq, H., and Pitrat, M. 1997. Two complementery recessive genes conferring resistance to Cucurbit aphid borne yellows Luteovirus in an Indian melon line (Cucumis melo L.). Euphytica 96:391-395.

14. Dogimont, C., Slama, S., Martin, J., Lecoq, H., and Pitrat, M. 1996. Sources of resistance to Cucurbit aphid-borne yellows Luteovirus in a melon germ plasm collection. Plant Dis. 80:1379-1382.

15. Duffus, J. E., Mayhew, D. E., and Flock, R. A. 1982. Lettuce infectious yellows - A new whitefly transmitted virus of the desert southwest. (Abstr.) Phytopathology 72:963.

16. Felsenstein, J. 1981. Evolutionary trees from DNA sequences: A maximum likelihood approach. J. Mol. Evol. 17:368-376.

17. Figueira, A. R., Domier, L. L., and D'Arcy, C. J. 1997. Comparison of techniques for detec- 
tion of Barley yellow dwarf virus-PAV-IL. Plant Dis. 81:1236-1240.

18. Fitch, W. M. 1971. Toward defining the course of evolution: Minimum change for a specific tree topology. Systematic Zool. 20:406-416.

19. Garzo, E. I., Duque, M., and Fereres, A. 2004. Transmission efficiency of different nonpersistent viruses infecting melon by four aphid species. Spanish J. Agric. Res. 2:369376.

20. Guilley, H., Wipf-Scheibel, C., Richards, K., Lecoq, H., and Jonard, G. 1994. Nucleotide sequence of Cucurbit aphid-borne yellows luteovirus. Virology 202:1012-1017.

21. Guyader, S., and Giblot, D. D. 2002. Sequence analysis of Potato leafroll virus isolates reveals genetic stability, major evolutionary events and differential selection pressure between overlapping reading frame products. J. Gen. Virol. 83:1799-1807.

22. Jacobi, V., Bachand, G. D., Hamelin, R. C., and Castello, J. D. 1998. Development of a multiplex immunocapture RT-PCR assay for detection and differentiation of tomato and tobacco mosaic Tobamoviruses. J. Virol. Methods 74:167-178.

23. Jebari, H., El Mahjoub, M., and Mnari-Hattab, M. 2004. La culture du melon en Tunisie. Documents techniques INRAT 118 , ISSN0020-238X

24. Jordá-Gutiérrez, G., Gómez-Guillamón, M. L., Júarez, M., and Alfaro-García, A. 1993. Clostero-like particles associated with a yellows disease of melons in south-eastern Spain. Plant Pathol. 42:722-727.

25. Júarez, M., Truniger, V., and Aranda, M. A. 2004. First report of Cucurbit aphid-borne yellows virus in Spain. Plant Dis. 88:907.

26. Kassem, M. A., Sempere, R. N., Juárez, M., Aranda, M. A., and Truniger, V. 2007. Cucurbit aphid-borne yellows virus is prevalent in field-grown cucurbit crops of southeastern Spain. Plant Dis. 91:232-238.

27. Lecoq, H. 1990. Aphid borne viruses infecting cucurbits in southern France: Ecology, epidemiologie and approaches for control. Pages 8385 in Proc. Congr. Mediterr. Phytopathol. Union, 8th. Agadir, Maroc.

28. Lecoq, H. 1999. Epidemiology of Cucurbit aphid-borne yellows virus. Pages 243-248 in: The Luteoviridae. H. G. Smith and H. Baker, eds. CABI Publishing, Wallingford, UK

29. Lecoq, H., Bourdin, D., Wipf-Scheibel, C., Bon, M., Lot, H., Lemaire, O., and Herrbach, E. 1992. A new yellowing disease of cucurbits caused by a luteovirus, Cucurbit aphid-borne yellows virus. Plant Pathol. 41:749-761

30. Lecoq, H., Dafalla, G., Desbiez, C., WipfScheibel, C., and Kheyr-Pour, A. 2003. A 10year survey (1993-2002) of cucurbit viruses in Sudan. J. Plant Dis. Prot. 110:68-69.

31. Lemaire, O. J., Gubler, W. D., Valencia, J., Lecoq, H., and Falk, B. W. 1993. First report of Cucurbit aphid borne yellows Luteovirus in the United States. Plant Dis. 77:1169.

32. Letschert, B., Adam, G., Lesemann, D. E., Willingmann, P., and Heinze, C. 2002. Detection and differentiation of serologically crossreacting Tobamoviruses of economical importance by RT-PCR and RT-PCR-RFLP. J. Virol. Methods 106:1-10.

33. Liu, H.-Y., and Duffus, J. E. 1990. Beet pseudo-yellows virus: Purification and serology. Phytopathology 80:866-869.

34. Livieratos, I. C., Avgelis, A. D., and Coutts, R. H. A. 1999. Molecular characterization of the cucurbit yellow stunting disorder virus coat protein gene. Phytopathology 89:1050-1055.

35. Mansilla, C., Sanchez, F., and Ponz, F. 2003. The diagnosis of the tomato variant of Pepino mosaic virus: An IC-RT-PCR approach. Eur. J. Plant Pathol. 109:139-146.

36. Mnari, M., Cherif, C., and Jebari, H. 1990. Importance des virus des Cucurbitacées en Tunisie et Etude des souches du virus de la mosaïque du concombre. Ann. INRAT 63(7):15pp.

37. Mnari-Hattab, M., and Cherif, C. 1992. Exposure periods in relation with infected potato progeny tubers. Abstr. posters presented Viruses Vectors and the Environment. Int. Plant Virus Epidemiology Sympos., 5th Valenzano (Bari) Italy, 27-31 July 1992.

38. Mnari-Hattab, M., and Ezzaier, K. 2006. Biological, serological, and molecular characterization of Pepper mild mottle virus (PMMoV) in Tunisia. Tunisian J. Plant Prot. 1:1-12.

39. Mnari-Hattab, M., Kummert, J., Roussel, S., Ezzaier, K., Zouba, A., and Jijakli, M. H. 2005. First report of Cucurbit aphid-borne yellows virus in Tunisia causing yellows on five cucurbitaceous species. Plant Dis. 89:776.

40. Ortiz, V., Castro, S., and Romero, J. 2005. Optimization of RT-PCR for the detection of Bean leaf roll virus in plant hosts and insect vector. J. Phytopathol. 153:68-72.

41. Posada, D., and Crandall, K. A. 1998. MODELTEST: Testing the model of DNA substitution. Bioinformatics 14:817-818.

42. Provvidenti, R. 1996. Disease caused by vi- ruses. Pages 37-45 in: Compendium of Cucurbit Diseases. T. A. Zitter, D. L. Hopkins, an C. E. Thomas, eds. American Phytopathological Society, St. Paul, MN

43. Quiot, J. B., Marchoux, G., Douine, L., and Vigouroux, A. 1979. Ecologie et épidémiologie du virus de la mosaïque du concombre (5) Rôle des espèces spontanées dans la conservation du virus. Phytopathologie 11:325-348.

44. Saitou, N., and Nei, M. 1987. The NeighborJoining method: A new method for reconstructing phylogenetic trees. Mol. Biol. Evol. 4:406425.

45. Sefc, K. M., Leonhardt, W., and Steinkellner, H. 2000. Partial sequence identification of grapevine-leafroll-associated virus-1 and development of a highly sensitive IC-RT-PCR detection method. J. Virol. Methods 86:101106.

46. Swofford, D. L. 2002. PAUP*: Phylogenetic Analysis Using Parsimony (*and other methods). Sinauer Associates, Inc., Sunderland, MA

47. Thompson, J. D., Higgins, D. G., and Gibson, T. J. 1994. CLUSTAL W: Improving the sensitivity of progressive multiple sequence alignment through sequence weighting, positionsspecific gap penalties and weight matrix choice. Nucleic Acids Res. 22:4973-4680.

48. Tomassoli, L., and Meneghini, M. 2007. First report of Cucurbit aphid-borne yellows virus in Italy. New Dis. Rep. Vol. 14.

49. Van den Heuvel, J. F. J. M., and Peters, D. 1989. Improved detection of Potato leafroll vi rus in plant material and in aphids. Phytopathology 79:963-967.

50. Wetzel, $T$, Candresse, $T$, Macquaire, $G$ Ravelonandro, M., and Dunez, J. 1992. A highly sensitive immunocapture polymerase chain reaction method for Plum pox potyvirus detection. J. Virol. Methods 39:27-37.

51. Wisler, G. C., Duffus, J. E., and Li, R. H. 1998. Ecology and epidemiology of whiteflytransmitted closteroviruses. Plant Dis. 82:270280.

52. Xiang, H. Y., Shang, Q. X., Han, C. G., Li, D. W., and Yu, J. L. 2007. First report on the occurrence of Cucurbit aphid-borne yellows virus on nine cucurbitaceous species in China. New Dis. Rep. Vol. 15.

53. Zeyen, R. J., Stromberg, E. L., and Kuehnast, E. L. 1987. Long-range aphid transport hypothesis for Maize dwarf mosaic virus: History and distribution in Minnesota, USA. Ann. Appl. Biol. 111:325-336. 